\title{
South-Vergent Imbricate Fan in the Ikenodan Formation of the Shimanto Supergroup, Southern Kyushu, Japan
}

\author{
Shinsuke Doi ${ }^{*}$, Hiroshi Yamamoto, Takashi Tominaga and Hafiz Ur Rehman
}

Department of Earth and Environmental Sciences, Graduate School of Science and Engineering, Kagoshima University, Kagoshima 890-0065, Japan

\begin{abstract}
The Noda area in the Hokusatsu District, southwest Kyushu is underlain by the Imanokoba, the Ikenodan and the Ogakura Formations of the Cretaceous Shimanto Supergroup. The Imanokoba Formation comprises beds of sandstone and mudstone. The beds generally trend NE-SW and dip in a moderate to steep angles to the east or west. The Ikenodan Formation comprises beds of sandstone, mudstone, siliceous mudstone and chert and basaltic lavas. The beds generally strike between NE and NW, and dip toward the west in moderate to high angles with a westerly way-up. The chert and basaltic lava beds appear in a left-stepping en echelon arrangement. The contact between the Imanokoba and the Ikenodan Formations is in a N-S trending fault known as the Noda Fault. The Ogakura Formation is composed of alternating beds of sandstone and mudstone. The beds generally strike between NE and NNE and dip toward the west in moderate to high angles with westerly way-up. The contact relationship between the Ikenodan and the Ogakura Formations is not distinct. The westward disappearance of the basaltic lava marks the western limit of the Ikenodan Formation. The en echelon array in the Ikenodan Formation is interpreted as an imbricate fan with the Noda Fault on its bottom as a décollement and is called "the Ikenodan imbricate fan". The Ikenodan imbricate fan is considered to have been formed in an accretionary complex developed in a northbound subduction zone. The primary attitude of the Ikenodan imbricate fan was probably south-vergent then turned over with its west side down. It was previously reported that the strata of the Shimanto Supergroup in the Hokusatsu area form a regional bending structure called the "the Hokustasu Bend". The Noda area is situated in a hinge zone of the Hokusatsu Bend, although the formations in the Noda area have not been involved in the bending structure. The Ikenodan Formation and the Noda Fault presumably extend to the north without bending, otherwise the bending structure occurs anywhere outside the Noda area. In either case, the Hokusatsu Bend is not present as interpreted in the previous studies.
\end{abstract}

Keywords: Shimanto Belt, Cretaceous, imbrication, structure, accretion, Hokusatsu District.

\section{INTRODUCTION}

The Shimanto Belt is the predominant tectonic unit in the Japanese-Ryukyu Islands (Fig. 1a, [1]). It is composed of Cretaceous, Paleogene and minor Neogene formations. These formations are collectively called the Shimanto Supergroup. Stratigraphic and structural studies of the Shimanto Supergroup have been carried out in many places. The previous studies revealed accretionary processes which worked during the development of the Shimanto Belt [e.g. 24]. Therefore, the term "the Shimanto accretionary complex" is widely used for various structural and stratigraphic units in the Shimanto Belt. This paper deals with the Cretaceous formations of the Shimanto Supergroup in the Hokusatsu District, southern Kyushu (Fig. 1b, [5]). The Hokusatsu District is situated at the junction of two island arc segments, the Southwest Japan Arc and the Ryukyu Arc [e.g. 6]. The Southwest Japan Arc trends ENE and the northern half of the Ryukyu Arc trends NNE. The trends of major tectonic units in southwest Japan including the Shimanto Belt bend about

*Address correspondence to this author at the Department of Earth and Environmental Sciences, Graduate School of Science and Engineering, Kagoshima University, Kagoshima 890-0065, Japan;

Tel: +81 99-285-8130; Fax: +81 99-259-4720;

E-mails: k8036405@kadai.jp, hyam@sci.kagoshima-u.ac.jp $40^{\circ}-50^{\circ}$ in and around the Hokusatsu District. Hashimoto [7] proposed a regional bending structure of the Shimanto Supergroup in the Hokusatsu District. This structure has been called "the Hokusatsu Bend" (Fig. 2) and has been generally accepted by succeeding researchers $[8,9]$. The Hokusatsu Bend is considered to have been formed during the opening of the Japan Sea in association with the clockwise rotation of the Southwest Japan Arc in Miocene time [7, 8, 10, 11]. Recently, Saito et al. [12] denied the bending structure without any definitive reasoning or supporting evidence. Apart from the Hokusatsu Bend, the structural aspects of the Shimanto Supergroup in the Hokusatsu District have not been well studied. We have investigated the central part of the Hokusatsu District form Sunahara to Ikenodan (Noda area, Fig. 2). Our results place new constraints on the structural setup of the formations in the Noda area and the tectonic model of the Shimanto Supergroup in the Hokusatsu District.

\section{GEOLOGIC SETTING}

The southern part of Kyushu is underlain by the rocks of the Chichibu and Shimanto Belts [1]. The Chichibu Belt is dominated by Jurassic formations and juxtaposed with the 


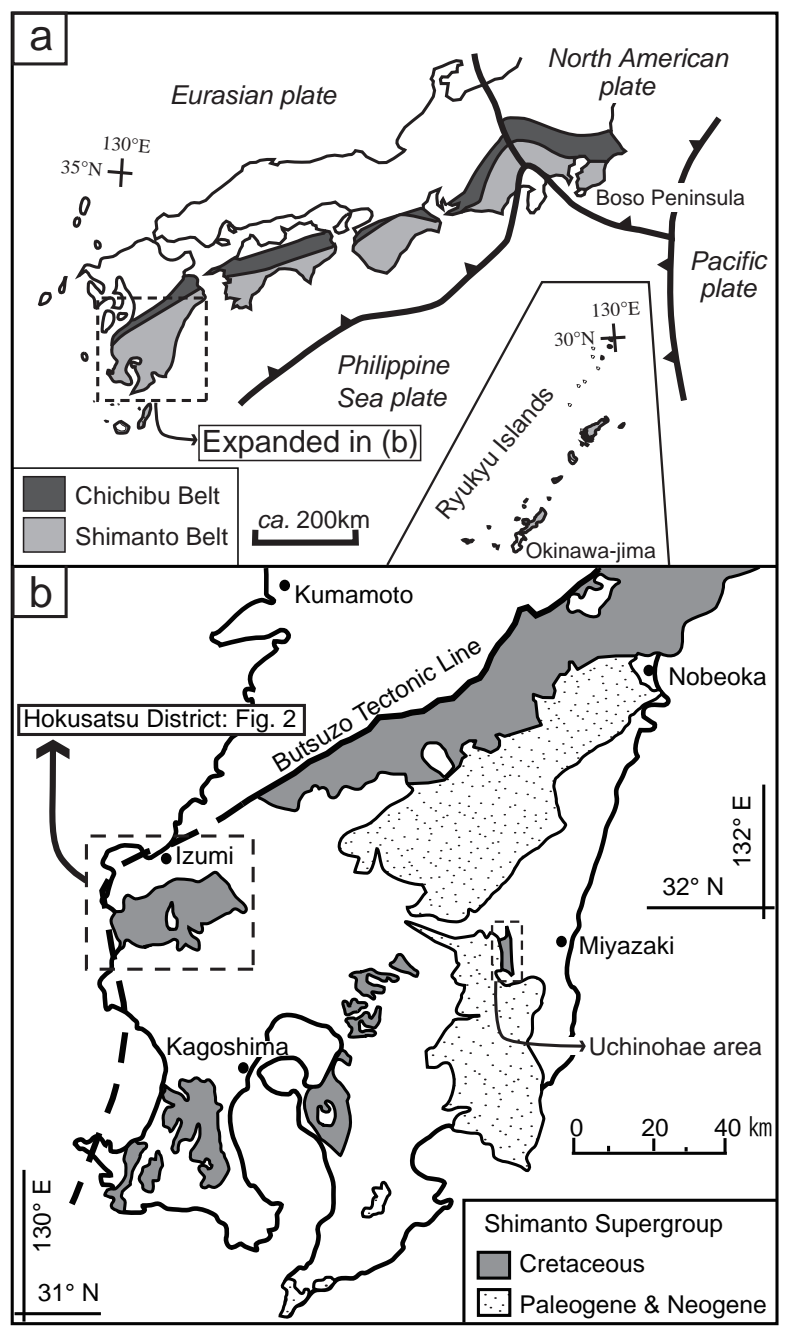

Fig. (1). (a) Distribution of the Chichibu-Shimanto Belts in the southwest Japan after Isozaki [1]. (b) Regional geological setting of the Shimanto Belt in the southern Kyushu. Geological boundaries are adapted and simplified from Teraoka [5].

Shimanto Belt. The Chichibu-Shimanto Belts are mapped from the Boso Peninsula in the Kanto region to Okinawajima of the Ryukyu Islands (Fig. 1a). The boundary between the Chichibu and Shimanto Belts is called "the Butsuzo Tectonic Line (BTL)" (Fig. 1b).

The Shimanto Belt in Kyushu is divided into the northern and the southern sub-belts. The northern sub-belt consists of Cretaceous formations and the southern sub-belt consists of Paleogene formations with minor successions of Neogene sediments. Formations of the northern sub-belt occur in the Hokusatsu District (Figs. 1b, 2). According to Yoneda and Iwamatsu [9], the Cretaceous formations in the Hokusatsu District are composed of the Okawa Group, the Takaono Group and the Kukino Formation. The Okawa Group is divided into the Ikenodan Formation and the Ogakura Formation. The Takaono Group is divided into the Inuyama, Hinotani and Imanokoba Formations. The Ogakura, Ikenodan and Imanokoba Formations lie in the Noda area

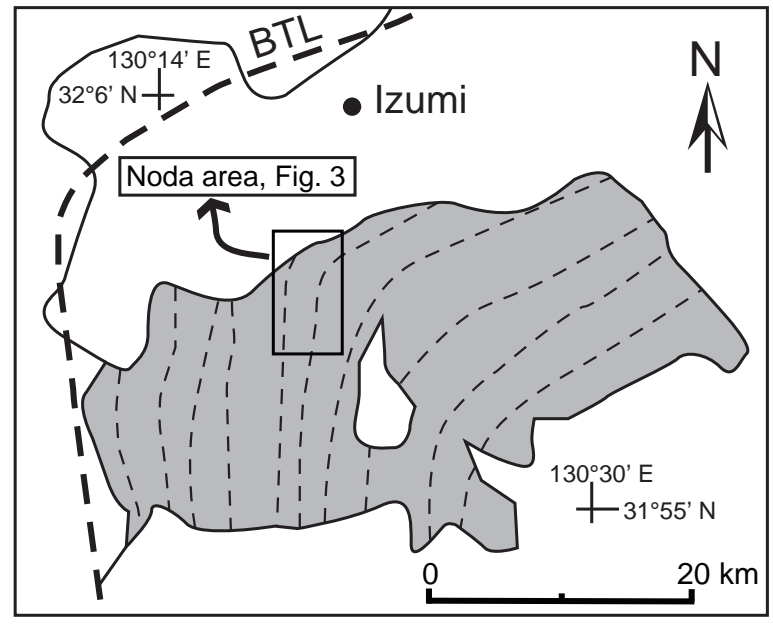

Fig. (2). Map showing distribution of the Shimanto Supergroup in the Hokusatsu District (grey-shaded area). Thin broken lines indicate trajectory of strike of bedding planes (showing "Hokusatsu Bend") after Hashimoto [7], Murata [8], and Yoneda and Iwamatsu [9]. "BTL" indicates the Butsuzo Tectonic Line.

(Fig. 3). The Imanokoba Formation consists of thick sandstone and mudstone. The Ikenodan Formation consists of sandstone, mudstone, siliceous mudstone, basaltic lava and chert. The Ogakura Formation consists of sandstone and mudstone. From Albian to Cenomanian ages were assigned to the Okawa and Takaono Group based on radiolaria [9]. The boundary between the Ikenodan Formation of the Okawa Group and the Imanokoba Formation of the Takaono Group has been considered to be a faulted contact [8, 9] termed "the Noda Fault" [9]. The Neogene-Quaternary volcanic rocks and volcaniclastic sediments widely cover the northern part of this area $[7-9,12]$.

\section{LITHOLOGIC DESCRIPTIONS}

\section{Imanokoba Formation}

The Imanokoba Formation in the study area is exposed from Sunahara to the south (Fig. 3). This formation consists of fine- to medium-grained sandstone, minor mudstone and rare interbedded sandstone and mudstone in places. The northernmost part of this formation is predominantly occupied by mudstone, which is generally homogeneous and has thin intercalated sandy and calcareous layers (Figs. 3, 4a). The mudstone-dominated layer strikes ENE-WSW, and dips $70^{\circ}-80^{\circ}$ toward north. The intercalated sandstone layers have graded bedding which indicates way-up to the north. To the south of the mudstone-dominated layer, the Imanokoba Formation is mainly composed of massive sandstone with thin intercalations of mudstone layers (Fig. 3). Fragments (up to $10 \mathrm{~mm}$ in diameter) of mudstone are common in the sandstone. This sandstone is a fine- to medium-grained feldspathic wacke, composed of clasts of quartz, plagioclase, K-feldspar and lithic fragments (Fig. 5a). Lithic fragments can be identified as felsic-intermediate volcanic rocks, chert, minor quartzose metamorphic rocks, and rare mafic volcanic rocks. A bedded variety of sandstone alternating with mudstone is distributed in places. The sandstone layers strike 


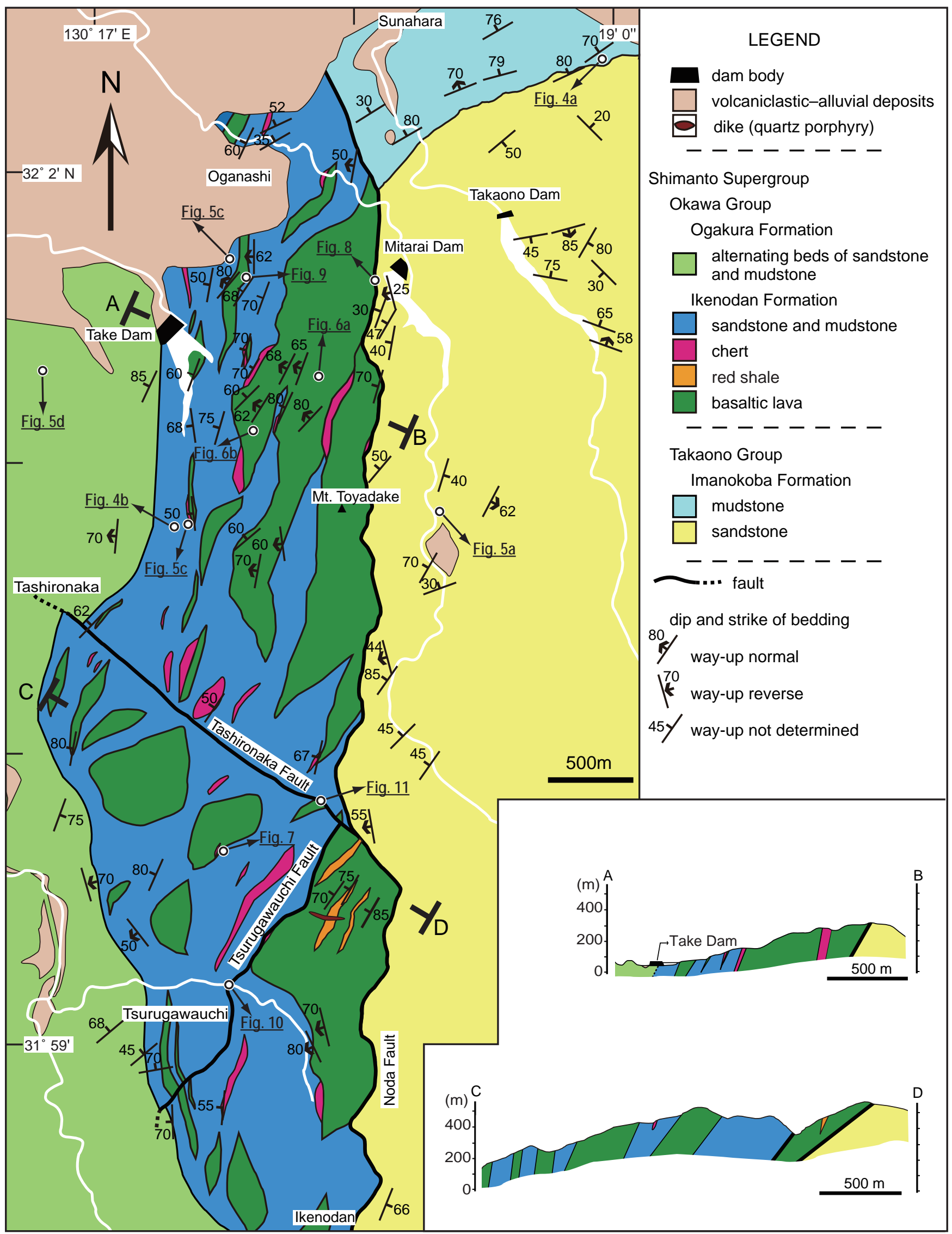

Fig. (3). Geological map and cross sections of the Noda area. 


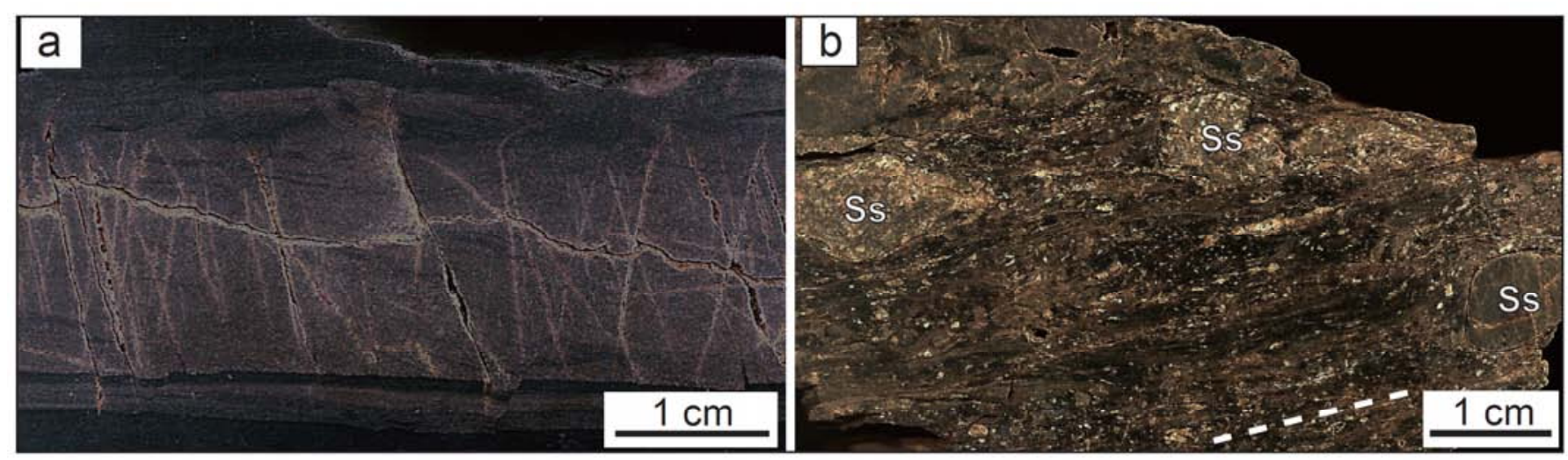

Fig. (4). Polished surfaces of mudstone samples (cut perpendicular to the bedding planes). See Fig. (3) for locations. (a) Imanokoba Formation. (b) Ikenodan Formation. A broken line in the lower-right of view indicates the trace of cleavage. Ss: clast of sandstone.
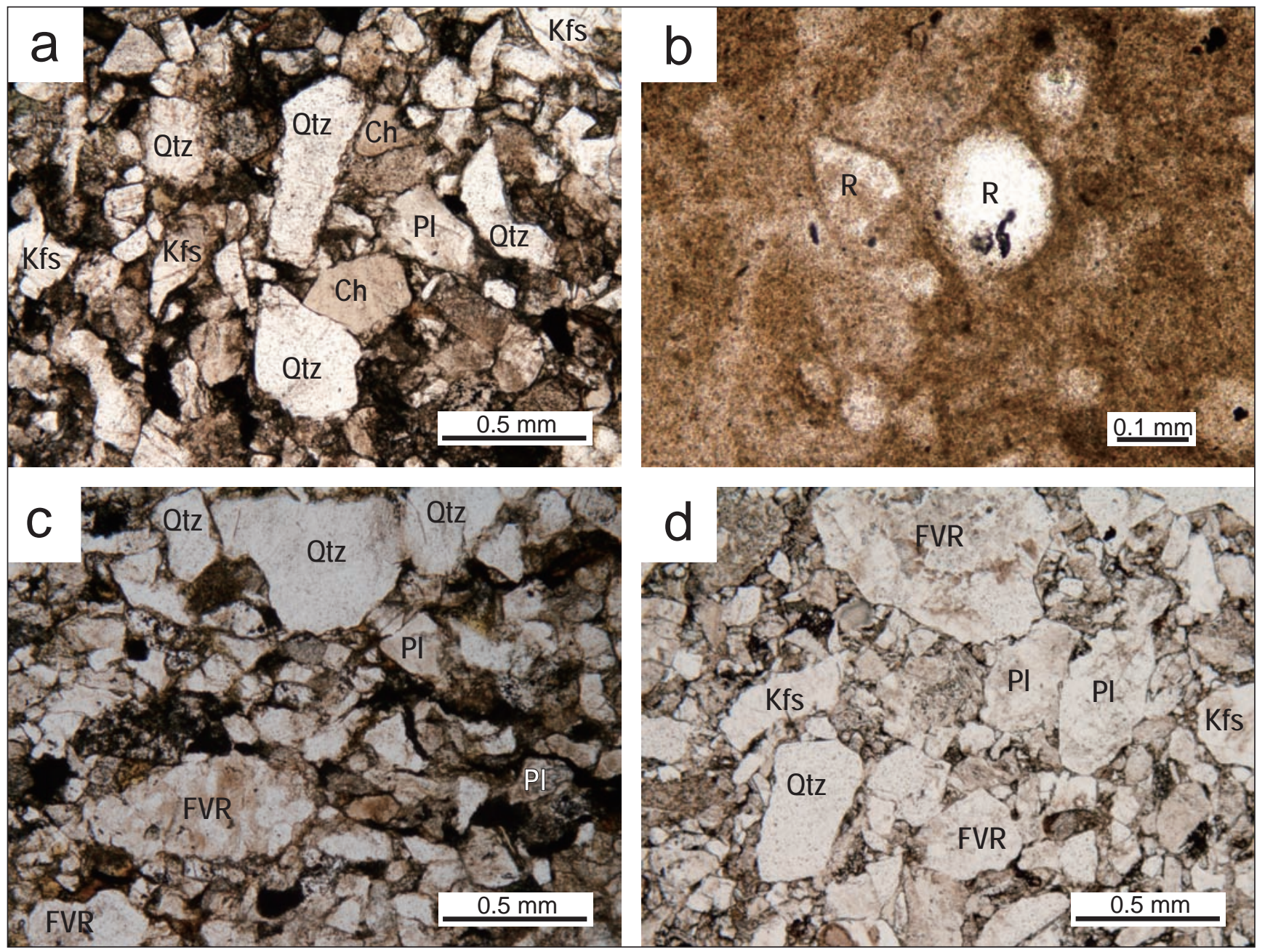

Fig. (5). Photomicrographs of the representative rock types (open polarized light). See Fig. (3) for locations. (a) Sandstone of the Imanokoba Formation, (b) Chert of the Ikenodan Formation, (c) Sandstone of the Ikenodan Formation, (d) Sandstone of the Ogakura Formation. Qtz: quartz, Pl: plagioclase, Kfs: K-feldspar, FVR: clast of felsic volcanic rocks, Ch: chert, R: radiolarian fossil.

between NE and WNW, and dip moderately or steeply. Dipdirections of the bedded sandstone are largely west or east and less commonly north or south. Graded bedding in the sandstone layers indicates various way-up directions (west, east, north and south). These observations suggest the presence of folding at mappable scales. However, we cannot show the outline of the fold because of the absence of a key bed which is traceable and can be used for identifying regional structure. 


\section{Ikenodan Formation}

The Ikenodan Formation occurs in a narrow zone extending north-south (Fig. 3). This formation is composed of basaltic lava, mudstone, siliceous mudstone and sandstone with minor chert. Most of the basaltic lava bodies show lenticular shapes, with minor bodies being pod-shaped. The lenticular bodies trend NNE, NS or NNW and dip $60^{\circ}-80^{\circ}$ toward west. The basaltic lava bodies commonly exhibit pillow structures which are generally smooth and convex towards the west (indicating structural top). The eastern sides are uneven and have protrusions (indicating structural bottom). In all observed cases, the pillow structures indicate way-up westward (Fig. 6). The lavas are composed of acicular-prismatic plagioclase, olivine, and pyroxene with accessories of opaque minerals. Olivine and pyroxene have been replaced by fine-grained mineral aggregates and represent as pseudomorphs by their short-prismatic shapes. Mudstone is the predominant rock type in the Ikenodan Formation. It is dark gray and commonly contains clasts (or blocks) of sandstone (ranging from one to $50 \mathrm{~cm}$ in diameter, Fig. 4b). A scaly cleavage (fissile along the cleavage and easily brakes into thin fragments like scales of a fish) is commonly recognized in the mudstone. Siliceous mudstones are pale gray or brick red and sporadically distributed in the dark-gray mudstone. In the southeastern part of the study area, a large basaltic lava body is intercalated with a reddish variety of siliceous mudstone. Chert occurs in bedded or massive varieties and appears in grayish, reddish or whitish colors. In the northern part of the study area, small lenticular bodies of chert tend to be accompanied by basaltic lava bodies. Interbedded chert and siliceous micrite occur above the basaltic lava bed in the south (Fig. 7). Chert and siliceous mudstone contain radiolaria (Fig. 5b). Thick layered (up to several tens of meters) and thin layered (less than a half meter) sandstone is interbedded with mudstone. These layers generally strike between $\mathrm{NE}$ and $\mathrm{NW}$, and dip toward the west in moderate to high angles with westerly way-up. The sandstone, a medium- to coarse-grained feldspathic wacke, is composed of quartz, plagioclase, K-feldspar and lithic fragments (Fig. 5c). Lithic fragments can be identified as felsic-intermediate volcanic rocks, chert, minor quartzose metamorphic rocks, and rare mafic volcanic rocks. The boundary between the Imanokoba Formation and the Ikenodan Formation is in a faulted contact (Fig. 8). The fault is corresponded to the Noda Fault that appears in Yoneda and Iwamatsu [9].

\section{Ogakura Formation}

The Ogakura Formation occurs in the western part of the study area. This formation consists of alternating beds of sandstone and mudstone. The sandstone occurs as thick (up to $200 \mathrm{~m}$ ) and thin layers (less than a half meter) interbedded with the mudstone. These layers generally strike between NE and NNE, and dip toward the west in moderate to high angles with westerly way-up. The sandstone is a mediumgrained feldspathic wacke, composed of clasts of quartz, plagioclase, K-feldspar, and lithic fragments. Lithic fragments are felsic-intermediate volcanic rocks, chert, minor quartzose metamorphic rocks, and rare mafic volcanic rocks (Fig. 5d). The boundary between the Ikenodan Formation and the Ogakura Formation is not very definitive but considered to be gradational. The strike, dip, and way-up of layers in the Ogakura Formation are conformable to those of the Ikenodan Formation. Distributions of the basaltic lava bodies and chert layers in the Ikenodan Formation tend to decrease westward. The disappearances of the basaltic lava and the chert are considered as the western limit of the Ikenodan Formation.

\section{STRUCTURE OF THE IKENODAN FORMATION WITH THE NODA FAULT}

The boundary between Ikenodan and the Imanokoba Formations, the Noda Fault, is traceable from Ikenodan to southwest of Sunahara (Fig. 3). The Noda Fault, for the most part, runs between the basaltic lava of the Ikenodan Formation on its west and the sandstone of the Imanokoba Formation on its east (Fig. 8). The fault dips around $60^{\circ}$ west in the northern and central parts of the study area. The dip angle decreases to $35^{\circ}$ in the southern part. The northern extension is covered with volcaniclastic and alluvial
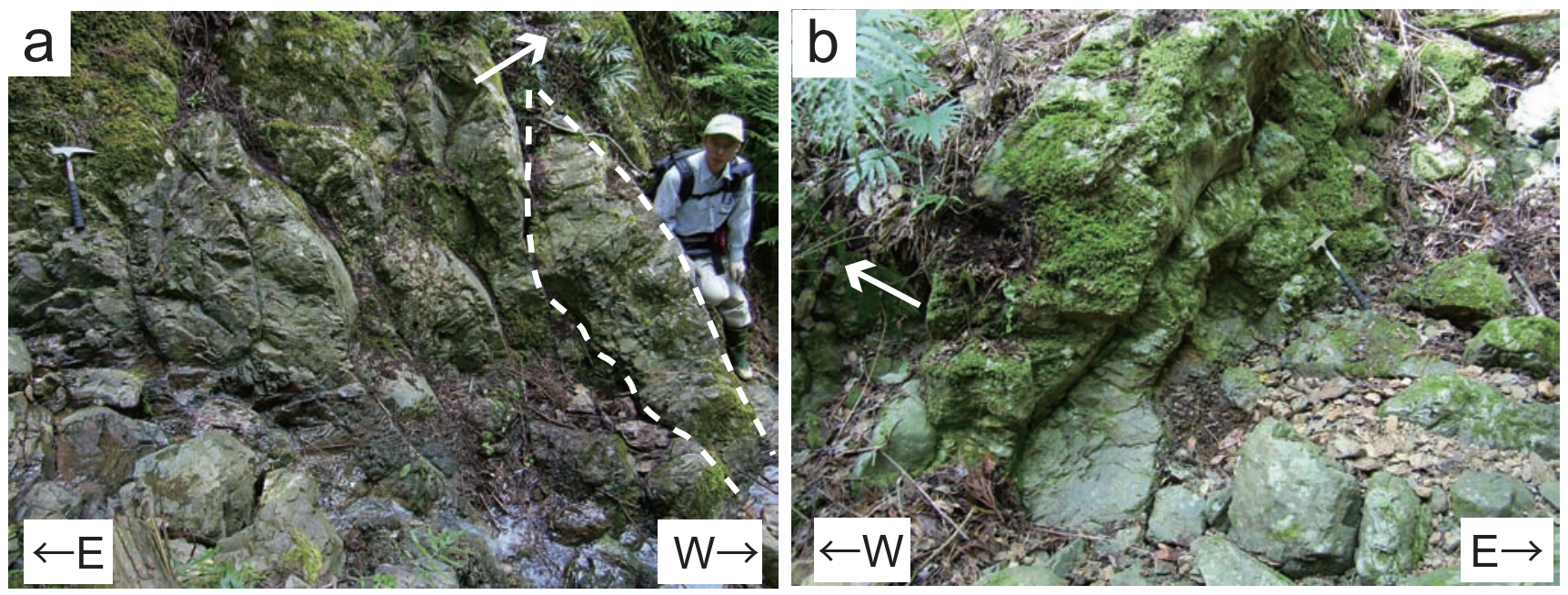

Fig. (6). Photographs of basaltic pillow lava. Way-up direction is indicated by arrows. See Fig. (3) for locations. (a) Outline of a pillow is indicated by a white broken line. Looking south. (b) Looking north. 
sediments. The mudstone of the Ikenodan Formation near Oganashi is scaly and rich in visible clasts. It is easily distinguishable from the homogeneous mudstone around Sunahara.

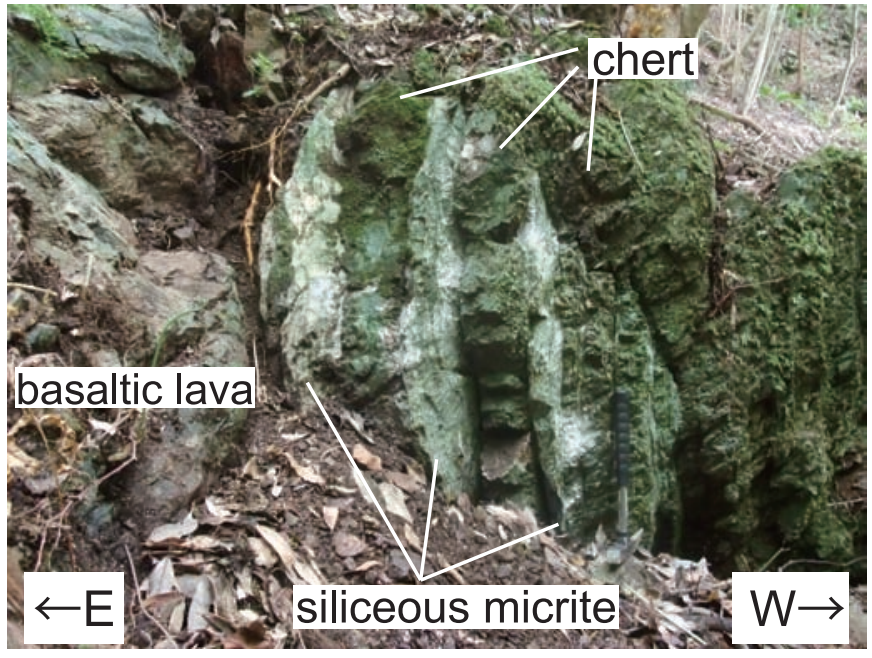

Fig. (7). Alternating beds of chert and siliceous micrite lying on the top of the basaltic lava bed. Looking south. See Fig. (3) for location.

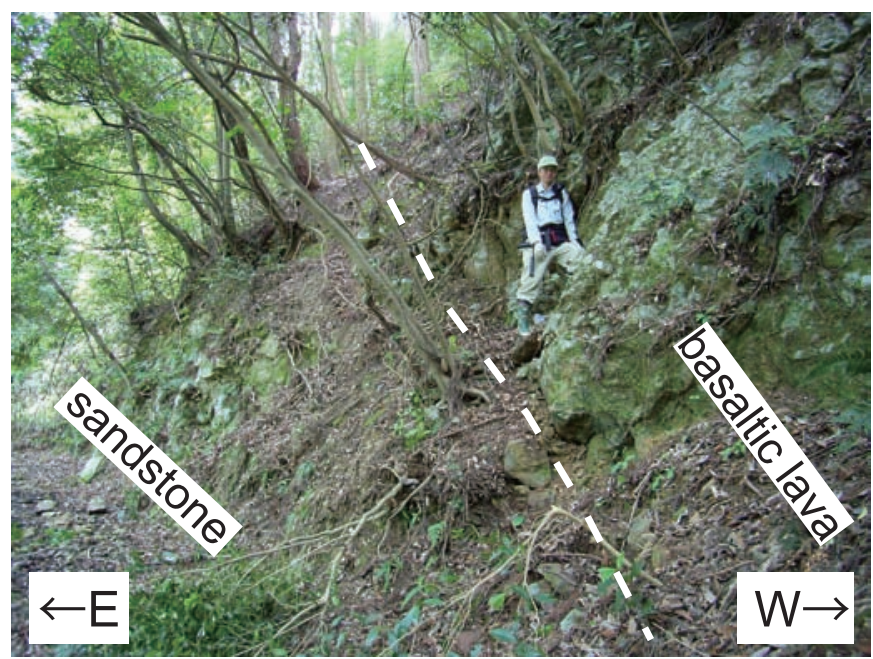

Fig. (8). Fault contact (indicated by a white broken line) of sandstone of the Imanokoba Formation and basaltic lava of the Ikenodan Formation (the Noda Fault). Looking south. See Fig. (3) for locations.

In the eastern part of the Ikenodan Formation, the basaltic lava is dominant over the mudstone (Fig. 3). The basaltic lava bodies beside the Noda Fault are generally thick and long, but those away from the Noda Fault tend to be small and isolated. The pillow structures indicate westerly way-up of the basaltic lava bodies. The eastern (bottom) sides of basaltic lava bodies are in tectonic contact with the mudstone or sandstone. An example of bottom boundary of a basaltic lava body is shown in Fig. (9). Basaltic lavas and the mudstone are bounded by a narrow fracture zone, where the mudstone has been mashed into small flaky fragments. Fracture cleavage is developed in the mudstone near the fracture zone. Layers of mudstone, siliceous mudstone, and chert overlie the basaltic lava bodies. There is no signature of the shear deformation along the top boundaries of basaltic lava bodies (Fig. 7). In the northern part of the Noda area, layers of basaltic lava and chert of the Ikenodan Formation seem to form a left-stepping en echelon arrangement.

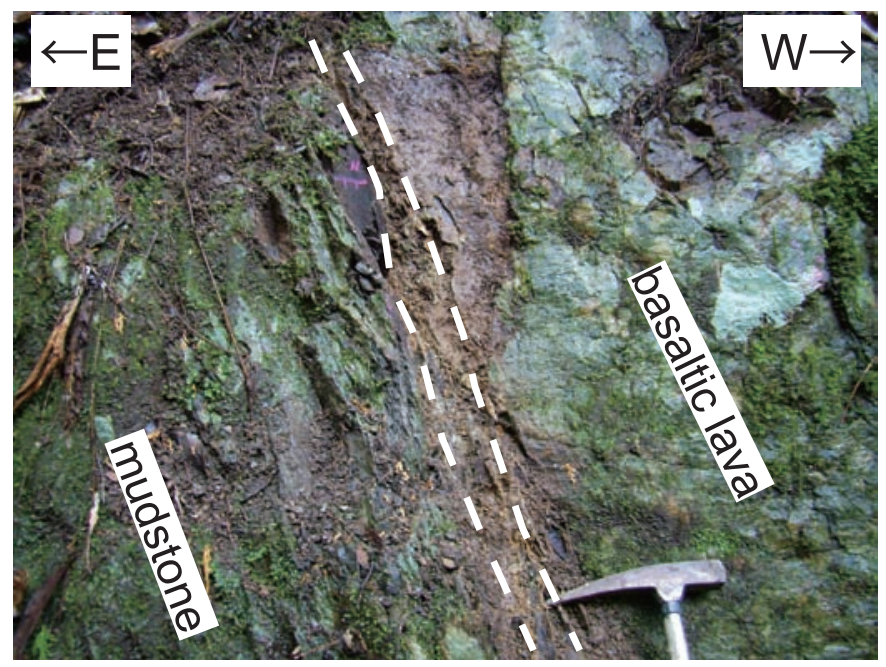

Fig. (9). A fault contact of basaltic lava and mudstone. A fracture zone on the bottom of basaltic lava is indicated by white broken lines. Fracture cleavage has been developed in the mudstone near the contact with the basaltic lava. Looking south. See Fig. (3) for location.

In the southern part of the Noda area, the structure of the Ikenodan Formation is characterized by two transverse faults: the Tsurugawauchi Fault and the Tashironaka Fault (Fig. 3). The Tsurugawauchi Fault runs to the east of Tsurugawauchi. It strikes NNE-SSW and dips 50-60 ${ }^{\circ}$ west. An example of a brittle shear zone along the Tsurugawauchi Fault can be seen in the field (Fig. 10a). A fracture zone (ca. $5 \mathrm{~cm}$ thick) filled with brecciated mudstone has developed between the layers of sheared mudstone. Strike and dip of the fracture zone is $\mathrm{N} 20^{\circ} \mathrm{E}$ and $50^{\circ} \mathrm{W}$, respectively. Slickensides on the exposed surface of footwall trend $\mathrm{N} 3^{\circ} \mathrm{W}$ and plunge $26^{\circ} \mathrm{N}$. Quartz veins are conspicuous in the footwall mudstone. Some of the quartz veins form an imbricate stack indicating left-lateral strike-slip displacement (Fig. 10b). The mudstone on the hanging wall shows well developed fracture cleavage.

A transverse structural discontinuity is traceable along a deep valley from Tashironaka to the southeast (Fig. 3). The Tashironaka Fault is delineated by several scattered outcrops of brittle shear zones in the valley. The Tashironaka Fault generally strikes NW-SE and dips south about $80^{\circ}$. An exposure of the Tashironaka Fault is shown in Fig. (11). The hanging wall is represented by basaltic lava and the footwall is composed of mudstone. Strike and dip of the faulted surface are EW and $87^{\circ} \mathrm{S}$, respectively. Slickensides on the hanging wall plunge $6^{\circ}$ to the east. The fault plane has an opening of up to $10 \mathrm{~cm}$ which is filled with loose soil. The distribution pattern of the basaltic lava bodies around the junction of these faults together with the subhorizontal slickensides suggest right-lateral strike-slip displacement of the Tashironaka Fault. The northern extension of the Tsurugawauchi Fault reaches to the Tashironaka Fault and it is not traceable beyond the Tashironaka Fault. These faults seem to form "V" shape with its top facing west. Blocks and lenses of basaltic lava are scattered between the faults. 


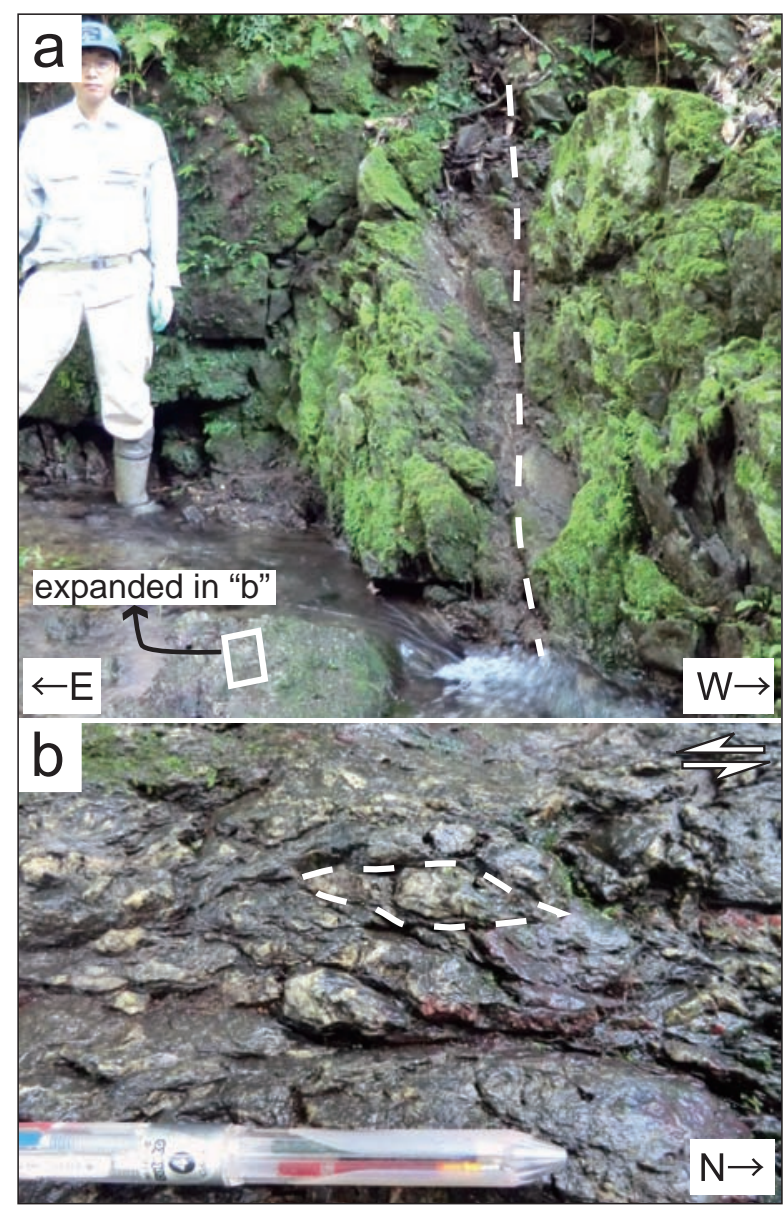

Fig. (10). (a) An exposure of brittle shear zone of the Tsurugawauchi Fault. Strike and dip of the fracture zone (white broken line) is $\mathrm{N} 20^{\circ} \mathrm{E}$ and $50^{\circ} \mathrm{W}$. Slikensides on the footwall trend $\mathrm{N} 3^{\circ} \mathrm{W}$ and plunge $26^{\circ} \mathrm{N}$. See Fig. (3) for location. (b) Imbricate stack of quartz veins indicating left-lateral shear. Looking downward.

\section{TECTONIC INTERPRETATIONS}

\section{South-Vergent Imbricate Fan}

Thrust faults arranged in an en echelon manner in crosssection are generally described as "imbricate" and a series of imbricate thrusts that branch out from a deeper thrust are known as "imbricate fan" [e.g. 13]. Structural features of the Ikenodan Formation can be summarized as follows. The basaltic lava and chert bodies present a left-stepping en echelon arrangement. The basaltic lava bodies are way-up westward and their bottom boundaries are in fault contact with mudstone and sandstone. Some of the bottom boundaries converge on the Noda Fault (Fig. 3). The en echelon array in our geological map is analogous to an imbricate fan, although it does not appear in cross-section. The structural setting of the Ikenodan Formation with the Noda Fault leads to an interpretative model for the tectonic development of the Noda area (Fig. 12). The formation of en echelon array in the Ikenodan Formation is attributable to the

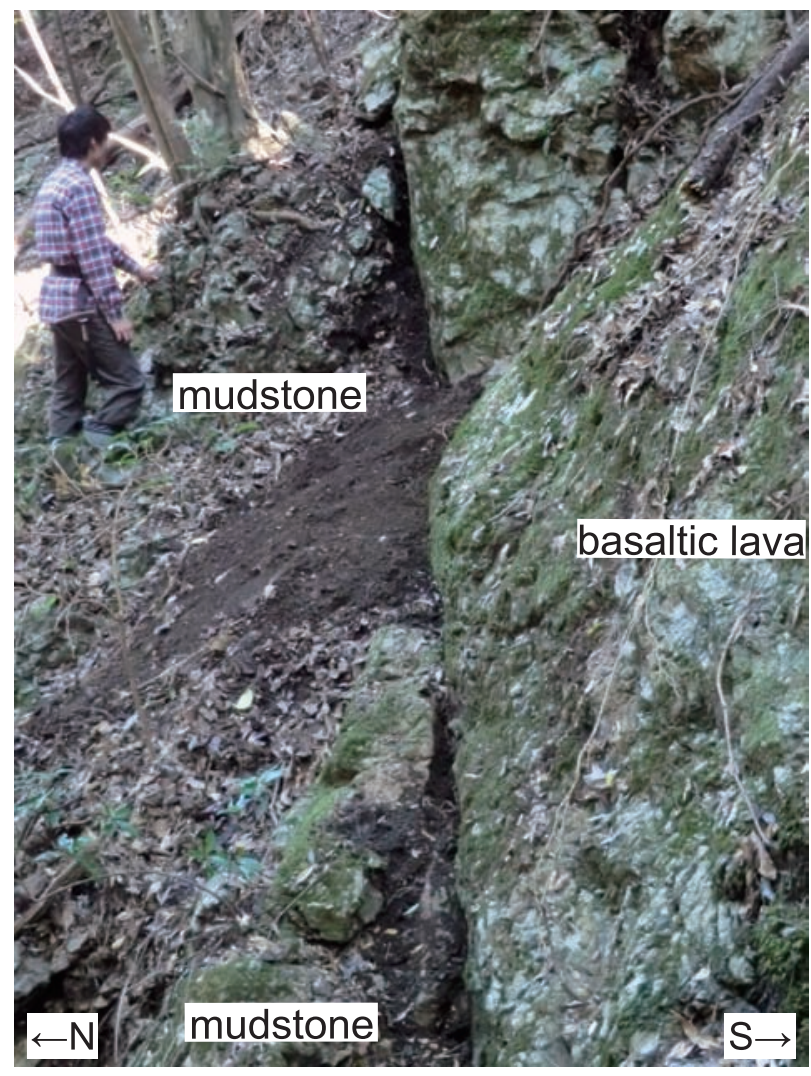

Fig. (11). A fault contact between basaltic lava and mudstone (the Tashironaka Fault ). Strike and dip of the fault are EW and $87^{\circ} \mathrm{S}$ respectively. Looking east. See Fig. (3) for location.

left-lateral displacement of the Noda Fault. Accordingly, the en echelon array is interpreted as an imbricate fan with the Noda Fault on its bottom as a décollement, termed here "the Ikenodan imbricate fan". This imbricate fan is considered to have been formed in an accretionary complex developed as a result of northward subduction of the oceanic lithosphere. The primary orientation of the Ikenodan imbricate fan was probably south-vergent then it turned over, west side down. Thus the Ikenodan imbricate fan has been exposed to the ground surface in the Noda area and can be seen like a crosssection (Figs. 3, 12).

Another example of an overturned imbricate structure is exposed in the Uchinohae area, southeast Kyushu (Fig. 1b) and it is called "the Uchinohae Duplex" [14]. The Cretaceous Uchinohae Formation trends NNE-SSW, dips toward east with easterly way-up. Imbricate structure (duplex) is denoted by a right-stepping en echelon array of basaltic rock units. The floor thrust of the Uchinohae Duplex is called the Takaoka Thrust and it separates the Cretaceous Uchinohae Formation from the Paleogene Yamanoguchi Formation. The Ikenodan imbricate fan and the Uchinohae Duplex seem to be mirror images. Despite the structural resemblance between these areas, the Ikenodan imbricate fan cannot be correlated with the Uchinohae Duplex. Because the Noda Fault is a boundary between Cretaceous formations, the Ikenodan imbricate fan and the Uchinohae Duplex (Cretaceous-Paleogene boundary) are situated in different tectonic settings. According to Murata $[14,15]$ the 


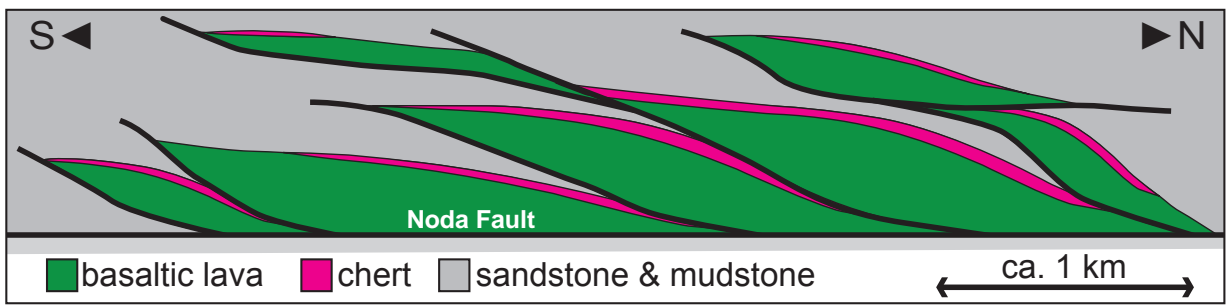

Fig. (12). Schematic diagram (projection to a ground plane) showing the tectonic interpretation of the Ikenodan Formation and the Noda Fault as an imbricate fan.

fundamental structure of the Shimanto Belt in Kyushu is composed of shallow-dipping or subhorizontal thrusts accompanied by several duplexes. The subhorizontal nappe structures and duplexes have been reported from several areas of the Shimanto Belt in eastern Kyushu [16, 17]. The results of this study present new and the first evidence of subhorizontal structure related to the development of the Shimanto accretionary complex in southwest Kyushu.

\section{The Hokusatsu Bend}

According to Murata [8] and Yoneda and Iwamatsu [9], the Cretaceous formations in the Hokusatsu District generally strike NE-SW in the northeastern part of their exposed area and $\mathrm{N}-\mathrm{S}$ in the southwestern part (Fig. 2). A hinge zone between $\mathrm{NE}-\mathrm{SW}$ and $\mathrm{N}-\mathrm{S}$ trending parts is indicated by the curved appearance of a basalt-bearing unit (the Ikenodan zone [8] or the Ikenodan Formation [9]). The strike of the Ikenodan zone is $\mathrm{N} 0^{\circ}-30^{\circ} \mathrm{E}$, to the south of Oganashi and it changes gradually to $\mathrm{N} 40^{\circ}-70^{\circ} \mathrm{E}$, to the east of Oganashi [8]. The Noda area includes their proposed hinge zone around Oganashi (Fig. 3). Detailed geological mapping has revealed that the basaltic lava bodies and the chert layers are not distributed around the Sunahara and Takaono Dam. The Ikenodan Formation (or the Ikenodan zone) in previous studies has been regarded as continuous around Oganashi [8,9], but it does not extend to the northeast from Oganashi to Sunahara. The Ikenodan Formation is in fault contact with the Imanokoba Formation. General trend of the Ikenodan Formation is N-S and that of the Imanokoba Formation is NE-SW. The structure of the Ikenodan Formation is not conformable with that of the
Imanokoba Formation. The northward continuation of the Ikenodan Formation is covered with volcaniclastic deposits and alluvial sediments. There is low-lying flat land called the Izumi Plain to the north of the Noda area. The Shimanto Supergroup may underlie the Izumi Plain. The results of this study indicate that the Shimanto Supergroup in the Noda area has not been involved in a bending structure. Apart from these local evidences, it is certain that the geotectonic framework of the southwest Japan has been bent in Kyushu from a broad perspective. Taking into account of the above discussion, two possible interpretations on the regional structure of the Shimanto Supergroup are illustrated in Fig. (13). In either case, "the Hokusatsu Bend" does not exist in the form that has been described in prior studies $[8,9]$.

(1) The hinge of regional bending structure is not exposed in the Noda area. The Noda Fault and the adjoining formations bend to the northeast under the Izumi Plain (Fig. 13a).

(2) The Ikenodan Formation and the Noda Fault extend to the Butsuzo Tectonic Line without bending (Fig. 13b).

The former makes minor alterations to the outline of the Hokusatsu Bend. The crucial part of bending structure is considered to be hidden underground. The latter is a challenge to the existence of bending structure. It suggests that NE-SW-trending and $\mathrm{N}-\mathrm{S}$-trending areas are in a fault contact. In this case, the Shimanto Supergroup is considered to have been tectonically eroded by the activity of the BTL. The third possible interpretation is that the northern extension of Noda Fault displaces the BTL. The Noda Fault

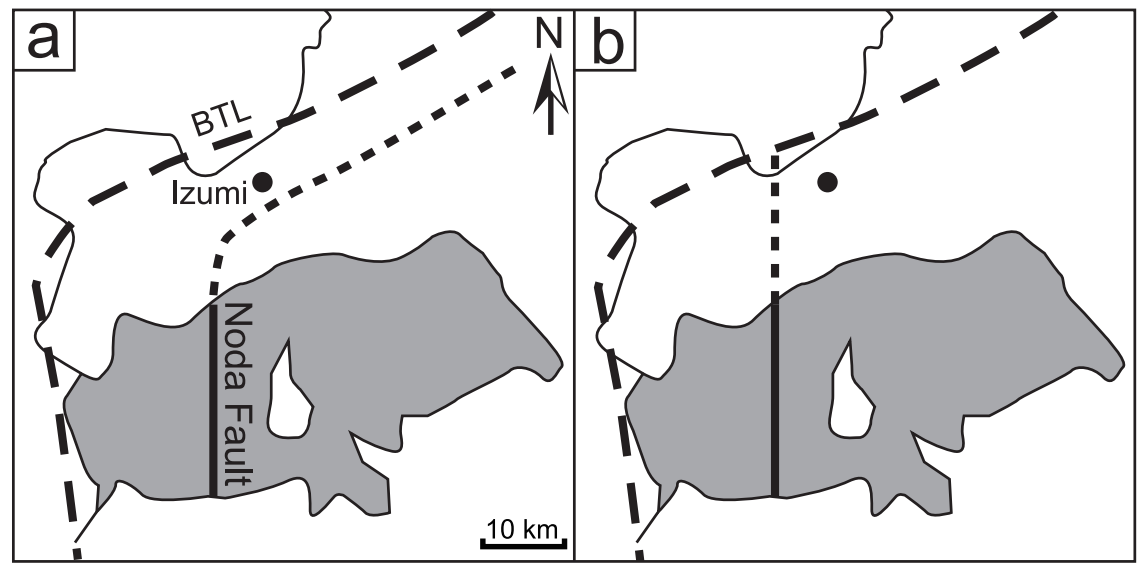

Fig. (13). Two explanatory models of the regional structure of the Hokusatsu District. (a) The Noda Fault and the adjoining formations bend to the northeast under the Izumi Plain. (b) The Noda Fault extends straight to the Butsuzo Tectonic Line. 
is an internal structure within the Shimanto Belt and can be related to the process of accretion. Thus it is hard to consider that the Noda Fault displaces the BTL.

The geological structure of the Izumi area is the key to elucidate whether the Shimanto Supergroup has been bent in the Hokusatsu District or not. Unfortunately, volcanicvolcaniclastic rocks and alluvial deposits widely cover the basement rocks. Extensive scientific drilling and geophysical exploration in the Izumi area are necessary before giving tectonic interpretations to "the Hokusatsu Bend".

\section{CONCLUDING REMARKS}

(1) The chert and basaltic lava beds in the Ikenodan Formation appear in a left-stepping en echelon arrangement.

(2) The en echelon array in the Ikenodan Formation is interpreted as an imbricate fan with the Noda Fault on its bottom as a décollement. We propose "the Ikenodan imbricate fan" for this structure.

(3) The Ikenodan imbricate fan is considered to have been formed in an accretionary complex developed in a northbound subduction zone. The primary attitude of the Ikenodan imbricate fan was probably southvergent then turned over with its west side down.

(4) The Noda area is situated in a hinge zone of the socalled "Hokusatsu Bend", however the formations in the Noda area have not been involved in the bending structure.

\section{CONFLICT OF INTEREST}

The authors confirm that this article content has no conflict of interest.

\section{ACKNOWLEDGMEENTS}

The authors would like to thank the editor B. J. Katz and an anonymous reviewer for their critical and constructive comments. This study was financially supported by the Grant-in-Aid for Scientific Research (KAKENHI) from the Japan Society for the Promotion of Science (No. 22540472).

\section{REFERENCES}

[1] Isozaki Y, Maruyama S, Furuoka F. Accreted oceanic materials in Japan. Tectonophysics 1990; 181: 179-205.

[2] Taira A, Okada H, Whitaker JHM, Smith AJ. The Shimanto Belt of Japan: Cretaceous-lower Miocene active-margin sedimentation. In: Leggett JK, Ed. Trench-forearc Geology: Sedimentation and Techtonics on Modern and Ancient Active Plate Margins. Geol Soc London, Spec Pub 1982; 10: 5-26.

[3] Taira A, Katto J, Tashiro M, Okamura M, Kodama K. The Shimanto Belt in Shikoku, Japan - evolution of Cretaceous to Miocene accretionary prism. Modern Geol 1988; 12: 5-46.

[4] Kimura G, Mukai A. Underplated units in an accretionary complex: Melange of the Shimanto Belt of eastern Shikoku, southwest Japan. Tectonics 1991; 10: 31-50.

[5] Teraoka Y. Shimanto Supergroup in Kyushu, Southwest Japan. Chishitsu News 2004; 599: 40-8.

[6] Kodama K, Tashiro H, Takeuchi T. Quaternary counterclockwise rotation of south Kyushu, southwest Japan. Geology 1995; 23: 8236.

[7] Hashimoto I. Geological Succession and structure of the undated strata in the Hokusatsu district, Kagoshima Prefecture. Rep Earth Sci Department of Gen Educ, Kyushu Univ. 1962; 8: 47-62.

[8] Murata A. Hokusatsu Bend and clockwise rotation of the Southwest Japan Arc. J Fac Sci Univ Tokyo 1987; 21: 333-49.

[9] Yoneda I, Iwamatsu A. Stratigraphy and geologic structure of the Shimanto supergroup in the Hokusatsu district, Kagoshima Prefecture, South Kyushu, Japan. J Geol Soc Jpn 1987; 93: 881-95.

[10] Torii M, Hayashida A, Otofuji Y. The rotation of Southwest Japan and the formation of the Sea of Japan. Science (Kagaku) 1985; 55: 47-52.

[11] Otofuji Y, Matsuda T. Amount of clockwise rotation of Southwest Japan - fan shape opening of the southwestern part of the Japan Sea. Earth Planet Sci Let 1987; 85: 289-301.

[12] Saito M, Takarada S, Toshimitsu S, et al. Geological Map of Japan 1:200,000, Yatsushiro and a part of Nomo Zaki: Geol Sur Japan, AIST 2010.

[13] Boyer S E, Elliott D. Thrust Systems. Am Assoc Petrol Geol Bull 1982; 66: 1196-1230.

[14] Murata A. Duplex structures of the uchinohae formation in the shimanto terrane, Kyushu, Southwest Japan. J Geol Soc Jpn 1991; 97: 39-52.

[15] Murata A. Duplexes and low-angle nappe structures of the Shimanto Terrane, southwest Japan. Mem Geol Soc Jpn 1998; 50: 147-58.

[16] Murata A. Red and green siliceous mudstones and duplexes of the paleogene hyuga group in the shimanto terrane in Kyushu. J Geogra (Chigaku Zasshi) 1995; 104: 82-93.

[17] Murata A. Nappe structures of the shimanto terrane of the mikadoosuzuyama area in east Kyushu. Nat Sci Res (Fac Integ Arts Sci, Univ Tokushima) 1996; 9: 49-61. 